Gastrointestinal stromal tumours (GIST) constitute a separate group of mesenchymal neoplasms of the gastrointestinal tract. They have been commonly recognized for a few years, they have created a new problem in medical practice. GIST are more often centred in the stomach. They equally affect female and male patients and occur mainly in patients older than 50 years of age. The clinical picture of the tumour is non-specific. Radical surgical treatment and molecularly targeted therapy with tyrosine kinase inhibitors are used in GIST treatment. Nursing practice with reference to GIST danger is connected with biopsychosocial interventions of perioperative, oncological and palliative procedures and involves the area of health education mainly oriented towards shaping preventive procedures which favour early disease detection and support therapy and recovery.

Key words: gastrointestinal stroma tumours, oncosurgery, molecular therapy, nursing care.

Contemp Oncol (Pozn) 2014; 18 (6): 384-390 DOI: 10.5114/wo.2014.40557

\section{Characteristics of gastrointestinal stromal tumours, diagnostic procedure and therapeutic management and main directions of nursing practice in gastrointestinal stromal tumours}

\author{
Grażyna R. Wiraszka ${ }^{1}$, Stanisław Głuszek ${ }^{1,2}$, Dorota Kozieł $\mathfrak{ł}^{1,2}$
}

${ }^{1}$ Institute of Nursing and Obstetrics, Faculty of Health Sciences, Jan Kochanowski University in Kielce, Poland

${ }^{2}$ Clinical Department of General, Oncological and Endocrinological Surgery, Voivodship, Hospital of Kielce, Poland

\section{Introduction}

Malignant neoplasms cause a serious problem of contemporary medicine in the world as well as in Poland. The data of the Polish National Cancer Register show that they are the second cause of deaths in our country, responsible for $26 \%$ of deaths in the male population and $23 \%$ of deaths in the female population. In addition, a constant increase in the incidence of cancer is observed. In 2009, there were 138000 new cases of malignant neoplasms (2100 more cases than in 2008). Taking completeness of registration into consideration it is estimated that in 2009 neoplasms were diagnosed in 156000 people and 320000 patients lived with diagnosed neoplastic disease [1].

It is indicated that two phenomena are responsible for the high risk of malignant neoplasms in the population of Poland - the size of exposure to risk factors and the delay in implementing early diagnosis and treatment programmes and their low efficiency [1].

Malignant neoplasms which arise out of epithelial tissue prevail in neoplasms recognized in various organ locations [1, 2]. Gastrointestinal stromal tumour (GIST), that is a stromal tumour of the gastrointestinal tract, one of many types of sarcomas (neoplasms arising out of connective, supportive, bone and muscular tissues) belongs to the group of neoplasms which do not have epithelial or glandular components [2, 3]. These neoplasms constitute a separate group of the most frequent mesenchymal tumours of the gastrointestinal tract, which concerns approximately $2 \%$ of all the tumours which are localized there [4-6].

The aim of this study is to analyse knowledge on epidemiology, pathogenesis, diagnosis and GIST treatment and attempt to determine the main directions of nursing practice within the scope of health education and interventions connected with diagnosis and tumour treatment.

\section{Origin and pathogenesis of gastrointestinal stromal tumours}

The present progress in research on pathogenesis of stromal tumours of the gastrointestinal tract has contributed to the isolation of GIST as a separate clinical and pathological unit and the creation of a model example of the efficient molecularly targeted therapy in treatment for tumours [7]. However, the history of diagnosis and research on this group of tumours has lasted for more than 70 years. Scientists T. Golden and A.P. Stout drew attention to neoplasms of mesenchymal origin developing in the gastrointestinal tract 
back in 1941 by describing cases of neoplasms arising in the bowel wall $[4,8,9]$. However, making a false assumption that these tumours arose out of cells of smooth muscles, they determined them based on the morphological classification of the time as leiomyoblastoma, leiomyoma, and leiomyosarcoma. In the 1960s and the beginning of the 1970s thanks to the achievements of electronic microscopy it was revealed that there was some evidence that few of these tumours originated from smooth muscle cells [4].

These observations were confirmed in the later research based on immunohistochemical techniques, conducted in the 1980s $[4,9,10]$. This notion of stromal tumours which did not specify the diversification line was proposed by Mazur and Clark in 1983 [4, 9]. In the subsequent research it was found that at least some of the gastrointestinal stromal tumours show the presence of S100 proteins and a relationship with Schwann cells and axons, which later were named gastrointestinal autonomic nerve tumours (GANT) $[4,9]$.

Since the beginning of the 1990s there have been many complexities in research on the histogenesis of GIST and some of them have seemed to show bidirectional differentiation [9]. It was found among other things that a substantial part of these changes contained the CD34 antigen, which was acknowledged as the most repetitive marker. However, during the next few years it turned out that only $60-70 \%$ of GIST are immunopositive for CD34, including the other recognized types of mesenchymal gastrointestinal neoplasms. This situation changed significantly in 1998 when Hirrota and his co-workers demonstrated c-kit mutation in the majority of cases of GIST [4, 9].

At present it is assumed that GIST come from progenitor cells of interstitial cells of Cajal (ICC), present in both layers of the muscular coat of the alimentary tube, responsible for both generating impulses which release free peristaltic waves and by means of the intermediaries transmitting impulses from the nerve fibres to smooth muscle cells. The neoplastic process is initiated by a mutation activating the gene encoding the membrane receptor KIT or PDGRFA [5, 9, 11-13] and has its excluding character [14]. The receptors possessing tyrosine kinase activity are the product of these two genes [14]. KIT by receiving signals of the stem cell growth factor (SCF; ligand kit) is responsible for the processes of development and growth of cells of Cajal. KIT activating mutation causes receptors to become metabolically active without the necessity of joining a ligand; even in the case of absence of a growth factor, there is constant uncontrollable cell division leading to the development of GIST [12-14]. Overexpression of the KIT membrane receptor is highly specific for GIST and possible to detect by immunohistochemical methods (CD 117) in histopathological tumour specimens [7, 15], which is the most important criterion in the microscopic diagnosis and treatment indications with tyrosine kinase inhibitors [7].

\section{Epidemiology}

According to the statistical data the annual incidence of GIST is estimated at 10-20 new cases per 1 million in- habitants; $20-30 \%$ of the cases are malignant neoplasms [16]. The inaccurate data that are currently available and still low detectability of GIST suggest that the rates might be significantly higher $[5,15]$. The accurate proportion between aggressive and benign tumours is also unknown [5]. On the basis of the data coming from the Swedish retrospective research on population the annual incidence of GIST is estimated at 15-16 cases per one million inhabitants and also on the basis of Dutch research the annual incidence of GIST is estimated at 12.7 cases per one million, but in Poland the annual incidence of GIST might be estimated at 600 new cases (3-4 cases per one million inhabitants). The similar analysis concerning non-operable GIST on the basis of the epidemiological data from the USA (the annual incidence of GIST is estimated at 1000 new cases, 3-4 cases per one million inhabitants) and the EORTC research (4-5 cases per one million per a year) indicates that 150-190 new non-operable disseminated cases of GIST might be expected in Poland [5, 15].

Gastrointestinal stromal tumour is not related to gender; it equally affects female and male subsets $[9,17]$. The occurrence of GIST is noted in all age groups. However, it mostly concerns adult patients older than 50 years of age [18], in whom the incidence is estimated at $75 \%$ of all cases [4]. The primary location of GIST is mostly connected with the alimentary tract; $90 \%$ of these neoplasms are located in it [5]. The most typical localization for GIST is the stomach, where $60 \%$ of all the tumours arise, $30 \%$ in the jejunum and the ileum, $5 \%$ in the duodenum and less than $5 \%$ in the colon. More rarely, cases are diagnosed in the oesophagus, the appendix and the gall bladder [17]. Gastrointestinal stromal tumours most seldom occur outside the tubal gut in locations such as the omentum, mesentery, or retroperitoneum, and have been referred to as extragastrointestinal stromal tumours (EGIST) $[6,19]$. Extragastrointestinal stromal tumours are poorly known and cause a lot of diagnostic and therapeutic problems [19]. The cases of GIST which require tyrosine kinase inhibitor therapy are most often centred in the small and large bowels.

\section{Clinical features}

Gastrointestinal stromal tumours may appear as tumours of different sizes and different rates of aggressiveness, ranging from small, benign tumours to large ones leading to massive metastases [7]. Small tumours, which remain asymptomatic for a long period of time, are sometimes identified incidentally during endoscopic examinations, surgical resection of other neoplasms or radiological imaging $[6,20]$. Gastrointestinal stromal tumours are located in the alimentary tract and according to their location they are called submucosal, intramural, or subserosal. In the endoscopic examination these tumours are more often depicted as submucous egg-shaped tumours, sometimes pedunculated, to different degrees having indentations in the lumen of the alimentary tract. In the case of bigger lesions, mucous membrane ulceration is often diagnosed [3].

Gastrointestinal stromal tumours manifest clinically with non-specific symptoms which vary depending on 
the size and location of the tumour [3]. The presenting symptoms include abdominal pain (50-70\%), and palpable masses in the abdomen $[5,6]$. The occurrence of early satiety is also observed [3]. In addition, fatigue and weakness secondary to iron deficiency anaemia may also occur as well as flatulence/distension with gas and constipation, especially when the tumour is localized in the lumen of the intestine. GIST sometimes take on an aggressive course with dissemination of numerous intraperitoneal nodules or with metastases to the liver [6]. It is estimated that malignant features with symptoms of infiltration and formation of metastases, especially intraperitoneal and to the liver, occur in $30 \%$ of cases. Metastases to the lymph nodes, lungs and extraperitoneal area are very rare [5].

\section{Diagnosis}

Gastrointestinal stromal tumours neoplasms have been commonly identified for a few years and the following methods are used in their diagnosis: methods of pathomorphological and molecular assessment, imaging methods, and biopsy examinations.

The aim of the pathomorphological assessment is to confirm the type of the tumour and its origin, and assess the degree of its aggressiveness on the basis of microscopic examination. Because these tumours in most cases are characterized by expression of the CD117 antigen (a protein produced by the KIT gene), pathomorphologists recommend confirmation of the identification by immunohistochemical methods allowing them to be detected. Only a few cases (below 5\%) are CD117 negative. Presently, histochemical methods are regarded as the most important criterion in a microscopic diagnosis of GIST and indications for treatment with micromolecular tyrosine kinase inhibitor [5, 15]. An assessment of the degree of malignancy of a neoplasm also has considerable importance. So far both benign and malignant histological tumours have been mentioned in GIST. However, at present pathologists avoid such a classification [9]. Currently, the scale of the risk of recurrence in patients after removal of a section of a primary GIST according to ESMO (2012) guidelines is recommended [21]. The basic prognostic factors are tumour size, number of mitoses counted in a high power field, and localization of GIST. Eight GIST prognostic groups (Table 1) have been distinguished based on tumour parameters and the percentage of relapses after surgical treatment (lower in tumours located in the stomach than in the large or small intestines) [21, 22].

The aim of molecular examination is to sequence whole genes and discover the presence of mutations in KIT and PDGFRA genes. They are observed most often in proto-oncogene c-KIT. About $70 \%$ of KIT mutations occur in exon 11, but 6-8\% concern exon 9 . Mutations may also occur in exons 13 and 17. Mutations in the PDGFRA gene occur in two PDGFRA exons, 18 and 11. The presence of mutated KIT or PDGFRA in the GIST is significant for predicting the response to imatinib treatment.

In the imaging diagnosis of the GIST dissemination computed tomography of the abdominal cavity is recommended (CT). It is used to assess the degree of tumour advancement and surgical procedure. In the case of a small tumour, endoscopic ultrasonography is also recommended $[5,15]$.

\section{Gastrointestinal stromal tumours treatment}

Gastrointestinal stromal tumours are refractory to the use of conventional chemotherapy and radiotherapy has limited value due to the localisation. The basic method of primary GIST which is regarded as the most efficient one is radical surgical treatment. Targeted therapy plays a significant role in the treatment of these neoplasms. It may be used thanks to the progress in discovering molecular mechanisms of GIST and is the model for molecularly targeted therapy in oncology [5, 7, 20, 23, 24]. It is underlined that due to the high risk of relapsing (about $40 \%$ after the primary surgical treatment), the therapeutic procedure should comprise treatment of GIST by multidisciplinary teams $[5,7]$.

The aims of surgical treatment depend on the degree of disease advancement. Radical resection of the primary tumour with intention to cure is of basic importance, and is used in cases of localised, resected GIST [5, 7, 15]. The resection rate of GIST is high and is assessed at the level 70-80\% [5]. In the case of non-resected, relapsing and/or metastatic forms of GIST where tyrosine kinase inhibitor therapy is chosen, surgery may be applied in removal of remnant lesions left after the molecularly targeted ther-

Table 1. Risk of recurrence in patients after removal of a section of a primary GIST - prognostic groups of different localization according to ESMO guidelines [21]

\begin{tabular}{|c|c|c|c|c|c|c|}
\hline \multirow{2}{*}{$\begin{array}{l}\text { Prognostic } \\
\text { group }\end{array}$} & \multicolumn{2}{|c|}{ Tumour parameters } & \multicolumn{4}{|c|}{ Percentage of recurrence after surgical treatment (\%) } \\
\hline & Tumour size $(\mathrm{cm})$ & Mitotic rate & Stomach & Duodenum & Jejunum/ileum & Rectum \\
\hline 1 & $\leq 2$ & \multirow{4}{*}{$\leq 5 / 50 \mathrm{HPF}$} & 0 very low & 0 very low & 0 very low & 0 very low \\
\hline 2 & $>2$ to $\leq 5$ & & 1.9 low & 8.3 low & 4.3 low & 8.5 low \\
\hline $3 a$ & $>5$ to $\leq 10$ & & 3.6 low & no data & 24 average & no data \\
\hline $3 b$ & $>10$ & & 12 average & 34 high & 52 high & 57 high \\
\hline 4 & $\leq 2$ & \multirow{4}{*}{$>5 / 50 \mathrm{HPF}$} & 0 very low & no data & 50 high & 54 high \\
\hline 5 & $>2$ to $\leq 5$ & & 16 average & 50 high & 73 high & 52 high \\
\hline $6 a$ & $>5$ to $\leq 10$ & & 55 high & no data & 85 high & no data \\
\hline $6 b$ & $>10$ & & 86 high & 90 high & 90 high & 71 high \\
\hline
\end{tabular}


apy. The aim of this treatment is to prolong survival time free from progression. The other important direction of surgical treatment is to cure acute complications of complementary therapy deriving from the course of the cancer process or sudden response to treatment - bleeding, gastrointestinal tract perforation, or abscess within a tumour - although they are rare situations and more often occur in the second line targeted treatment (sunitinib) [7].

Radical surgical treatment gives about 35\% to $65 \%$ fiveyear survival $[15,20]$. Performing the first operation with intention to cure is possible in about $75 \%$ of all patients and consists in open resection of the stomach, small intestine, large intestine or intraperitoneal or retroperitoneal tumours within macroscopically healthy tissues [5, 7, 15].

In cases of GIST located in the stomach, most often (in $37 \%$ of cases) wedge resection is performed, i.e. removal of the tumour with a part of the stomach wall [5, 15], and more seldom partial or total gastrectomy $(13 \%)[5,15,20]$. In GIST locations within the bowels segmental resection of the small intestine or hemicolectomy is carried out $[5,15$, 25]. As for the GIST, because of the fact that metastases to the lymph nodes occur occasionally and concern less than $3 \%$ of patients, there is no need to remove the locoregional lymphatic system $[5,7,15,20]$. In the case of primary GIST of large size, resection carried out by the laparoscopic method is not needed; however, in the case of tumours of smaller size the minimally invasive techniques will play a bigger and bigger role $[5,7]$.

In cases of GIST which are locally advanced, performing vast multiorgan resections is not recommended, as they are connected with the possibility of occurrence of short bowel syndrome or abdominoperineal rectum amputation [7]. In such a situation preoperative treatment with imatinib under the thorough control of computed tomography is considered, and the decision of surgical treatment is taken as a response to the applied treatment [7, 15, 20].

Observation may only be recommended in microscopically nonradical resections, although another resection may also be considered, which is conditioned by the possibility of localizing the primary tumour and excluding serious consequences for functioning of the alimentary tract $[5,7]$.

An especially important principle of therapeutic management during an operation of primary GIST is avoiding a situation in which a neoplasm may become damaged or broken, which could be the cause of intraperitoneal dissemination. This situation is regarded as an unfavourable carcinogenic factor and is more often the reason for emergency operations [5, 7, 15, 25-27]. Ruka and others $[7,20]$ systematized the principles of surgical treatment of primary GIST, mentioning apart from avoiding intraoperative tumour damage, the necessity of resection of the lesion within the margins of healthy tissues (margins 1-2 $\mathrm{cm}$ ), on principle lack of necessity of lymphadenectomy, uncertain role of laparoscopy contradicted in the case of big tumours, thorough assessment with respect to disease dissemination, consideration of neo-adjuvant imatinib instead of mutilating operations in the case of locally advanced GIST, and appropriate protection of tissues (freezing) for molecular research.
The risk of recurrence of the neoplasm is assessed in primary GIST patients after surgery confirmed by the result of histopathological study. Performing such a risk assessment based on the $\mathrm{NIH}$ classification defining the level of aggressiveness of tumours has been recommended so far [15]. Presently performing a risk assessment of neoplasm recurrence in primary GIST patients after surgery is carried out according to the classification by NCCN-AFIP-AJCC (National Comprehensive Cancer Network-Armed Forces Institute of Pathology-American Joint Committee on Cancer), taking into consideration tumour parameters (the size and the number of mitotic divisions) and the anatomical location of the primary GIST. Based on the classification, it is estimated that patients have a better prognosis if GIST are located in the stomach than in the large or small intestines $[5,7,27]$. The stages of tumour development can also be assessed based on the TNM classification which is recommended by the American Joint Committee on Cancer (AJCC) [20].

In patients in whom a high or intermediate level of aggressiveness is diagnosed, it is recommended to perform a precise observational study with the use of computed tomography (CT) of the abdominopelvic cavity, which should be carried out once every three months during the period of the first two years after the partial removal of the primary tumour. Between 2 and 5 years after the resection, the $\mathrm{CT}$ control may be performed more rarely - once every six months - but from 5 years after the resection once a year. Control examinations are recommended once a year in patients after resection of GIST of a low level of aggressiveness [5, 15].

An important role in GIST treatment is played by molecularly targeted therapy with the oral tyrosine kinase inhibitor imatinib [5, 7, 15, 23-25], but it is not a method for routine supplementary treatment [7]. However, this medicine is used in supplementary treatment after GIST resection associated with a significant risk of recurrence, in patients with an intermediate or high level of tumour clinical aggressiveness according to $\mathrm{NIH}$, although it is still a controversial method of therapy $[5,7]$. Imatinib is also used in cases of non-operative lesions where it is the method of choice for treatment. It is the first effective systemic treatment of advanced CD117-positive GIST, which brought fourfold prolonged long-term survival [7]. Presently it is assumed that treatment with imatinib is efficient and should be continued until tumour progression and discontinuation of treatment may cause rapid acceleration of the disease process [5]. There are classification criteria for treatment: a positive result obtained after performing an immunohistochemical staining experiment (CD117 positive), metastatic lesions and/or non-operable primary lesions and/or local relapses. The dose of medicine (400 or $800 \mathrm{mg}$ ) depends on the location of the mutation and tumour progression. The efficiency of treatment is monitored based on examination of computed tomography of the abdominal cavity with contrast media, assessing lesion size and lesion density. In about $40-50 \%$ of patients, treatment with imatinib during the period of 2-3 years leads to medicine (imatinib) resistance and tumour progression, which is most often the effect of acquisition of 
KIT or PDGRFA mutations by the neoplasm [7]. The possibility of using a second-line drug - the multikinase inhibitor sunitinib - is considered in such a situation [7, 28].

\section{Professional functions of a nurse versus gastrointestinal stromal tumours prevention, recognition and treatment}

Analysing the present level of knowledge on the aetiopathogenesis, the occurrence and the course and possibility of treating tumours at different sites as well as the level of knowledge on gastrointestinal stromal tumours, tasks of the nursing team can be considered in a few areas: preventive and educational, diagnostic and perioperative surgical care, oncological care and palliative care.

Taking into consideration neoplastic diseases, which belong to civilization-related diseases, of importance in their aetiology are various factors, defined as risk factors $[1,29]$, including behavioural and environmental factors, which determine trends of action within health promotion, prevention and health education. These actions usually include shaping pro-health behaviour within lifestyle [29]. However, the analysis of scientific works concerning GIST indicates that at present there is a lack of reports on risk factors leading to mutation in the Cajal cells and then the occurrence of GIST. Consequently there is a lack of possibility of creating specific educational programmes devoted to the threat of GIST tumour. The primary prevention may have only the character of non-specific reactions directed to the whole population and contributing to the general strengthening of health systems.

Considering the fact that a significant role in prognosing neoplasm cases including GIST is played by the earliest detection of a tumour [1], shaping preventive behaviour is an important field of educational action from secondary prevention (systematic registration for preventive examinations, self-observation, non-underestimation of the presenting symptoms) as well as shaping behaviour connected with the suspicion of disease (seeking professional aid, avoiding adoption of a passive attitude, self-treatment or withdrawal behaviours) [30]. These behaviours shaped in the general population may translate into earlier detection of neoplastic lesions, including GIST, especially because of the fact that symptoms of this tumour are often non-specific.

During the period of diagnosis as well as treatment of the disease, nursing care should have the character of individualized and holistic care, adapted to the individual needs and possibilities of a patient, and comprises biological and psychosocial problems of functioning of patients with the disease.

The basic method of treatment after diagnosing primary GIST, considered the most efficient one, is radical surgical therapy $[5,7,15]$. During this period of disease, nursing care will be focused on, among others, patient preparation for diagnostic procedures - CT, biopsy examinations or endoscopic ultrasonography. During the preoperative period, there are many duties a nurse provides to produce patient care: patients' preparation for surgery according to the obligatory procedures depending on the location of a tumour (stomach, small bowels, large bowels, oesophagus) and the treatment method which is planned [31]. This preparation comprises a patient's physical and mental wellbeing. In the early postoperative period, nursing intervention mainly aims at discovering life-threatening complications and fighting pain. Hence observation and monitoring of the functioning of the appropriate systems (respiratory, circulatory, urinary), monitoring of the intensity of pain and observation of anxious symptoms connected with surgical intervention in the abdominal cavity are extremely important. An important task in postoperative nursing care is prevention of postoperative complications including those resulting from the patient's immobilization (pneumonia, thrombophlebitis). The later period of nursing care focuses on gradual restoration of particular functions of the body, such as efficiency of the alimentary system, physical activity and self-dependence, as well as shaping beneficial behaviours connected with treatment and providing warning and recommendation advice, e.g. within systematic control, performing CT examinations and self-observation [31]. For patients with high and intermediate degrees of aggressiveness it is really important to undergo a thorough observation with computed tomography of the abdominopelvic cavity $[5,15]$.

Nursing care among others will focus on observation of the undesirable symptoms after the treatment with imatinib for patients with recommendations for molecularly targeted therapy with oral tyrosine kinase inhibitors [5, 7, $15,23]$ - in complementary treatment after GIST resection of significant risk of recurrence [5, 7] and as the treatment of choice in the case of non-surgical treatment of the lesions [7]. Symptoms and side effects including anaemia, oedema (swelling), weakness, nausea, diarrhoea, granulocytopenia, myospasms and cutaneous lesions concern most of the patients but their intensity is usually moderate and does not significantly influence everyday functioning. Spontaneous regression of some of the symptoms can occur. More dangerous complications such as bleeding from the tumour or the alimentary system, perforation of the alimentary system, stomach ache or retention of liquids also happen, though more rarely. Patients also require observation and sometimes medical interventions when they are treated with the second-line medicine sunitinib. This treatment causes weakness, diarrhoea, skin colour changes, nausea, mucous membrane inflammation, arterial hypertension, hyperthyroidism or impaired left ventricular function [20].

There is a lack of records of problems about GIST patients' functioning in different areas of life including the area of emotional functioning. Meanwhile, chronic disease causes a difficult situation for a patient, especially when malignant neoplasm is diagnosed. The analysis of academic literature indicates that diagnosing a neoplasm and the treatment connected with it, which often causes mutilation, are reasons for the occurrence of symptoms of fear, depression and other mental health disorders [32]. Hence, taking nursing care at every stage - perioperative, oncological, palliative - the assessment of emotional functioning and supportive actions within this area seems to be also justified for patients with GIST. A screening scale, 
e.g. recommended by de Walden-Gałuszko [32] (Hospital Anxiety and Depression), is used for assessment of the emotional state of a patient.

Emotional support given to a patient is expressed by among other things showing an appropriate attitude in the nurse-patient relationship. Thus contact with an ill person creates a specific interpersonal relationship. It is shaped by a difficult situation of a disease and a difficult life situation in which a patient has found themselves, on which such factors as features of the disease, its subjective image created by a patient, difficulties resulting from the disease, personality of a patient, defence and adaptive mechanisms, styles of coping with stress, and the social, family and professional situation of a patient have an influence [33]. Attitudes and an ability to create appropriate psychological conditions by members of a treatment and care team, their knowledge and competencies have an important meaning in shaping this relationship [33, 34]. The professional nurse-patient relationship needs to be guided by principles of therapeutic communication, understood as conscious use of well-matched selected verbal and non-verbal announcements and thanks to them to influence positively behaviour and emotions of a subject of care. It is most often connected with psychological support and it means a process having a positive influence on a subject [33]. Among many therapeutic behaviours such techniques as recognizing patients' needs, offering their time to a patient, therapeutic silence, active listening to a patient, enabling them to open widely, informing and encouraging them to describe their experiences may be used in the care of GIST patients $[35,36]$.

\section{Summary}

Gastrointestinal stromal tumours create a new problem in the clinical, diagnostic and therapeutic area and nursing practice. Radical surgical treatment and molecular target-based cancer therapy with tyrosine kinase inhibitors is used in GIST treatment. The development in research presently allows us to diagnose them and implement therapeutic procedures depending on the rate of aggressiveness of the tumour and the advancement of the neoplastic process. Lack of knowledge on risk factors initiating mutations and carcinogenesis prevents carrying out efficient preventive and educational activities. Nursing practice regarding the threat of GIST is connected with biopsychosocial interventions of perioperative, oncological and palliative procedures and includes the field of health education mainly focused on shaping preventive behaviours, favouring early discovery of a chronic disease and assisting therapy and return to health.

The authors declare no conflict of interest.

\section{References}

1. Didkowska J, Wojciechowska U, Zatoński W. Nowotwory złośliwe w Polsce w 2009 roku. Centrum Onkologii, Instytut im. M. Skłodowskiej-Curie w Warszawie, Warszawa 2011.
2. Wartenberg M, Reichardt P. GIST. Stowarzyszenie Pomocy Chorym na GIST. http://www.gist.pl/?id=2\&sid=1 - 26.VI.2013.

3. Cichoż-Lach H, Kasztelan-Szczerbińska B, Stomka M. Stromalne guzy przewodu pokarmowego - epidemiologia, obraz kliniczny, diagnostyka, rokowanie oraz zasady leczenia. Pol Arch Med Wewn 2008; 118: 1-5.

4. Laurini JA, Carter JE. Gastrointestinal stromal tumors. A review of the literature. Arch Pathol Lab Med 2010; 134: 134-41.

5. Rutkowski P, Kulig J, Krzakowski M, et al. Zasady postępowania diagnostyczno-terapeutycznego $u$ chorych na nowotwory podścieliskowe przewodu pokarmowego (GIST). Nowotwory 2011; 61: 70-80.

6. Deepa TP, Rubin BP. Gastrointestinal stromal tumor. Advances in diagnosis and management. Arch Pathol Lab Med 2011; 135: 1298-310.

7. Ruka W, Rutkowski P, Zdzienicki M, Nowecki ZI. Leczenie chirurgiczne nowotworów podścieliskowych przewodu pokarmowego (GIST). Gastroenterol Pol 2009; 16: 129-34.

8. Vilallonga R, Sanchez JL, Armengol M. Gastrointestinal stromal tumors: case of gastrointestinal bleeding. Gastroenterol Res 2010; 3: 93-5.

9. Fletcher Ch, Berman J, Corless Ch, et al. Diagnosis of gastrointestinal stromal tumors: a consensus approach. Hum Pathol 2002; 33: 459-65.

10. Rubin BP. Gastrointestinal stromal tumors: an update. Histopathology 2006; 48: 83-96.

11. Cichocki T, Litwin JA, Mirecka J. Kompendium histologii. Wydawnictwo UJ, Kraków 2009.

12. Lorincz A, Horváth VJ, Bardsley MR, Chen H, Ordog T. Progenitors of Interstitial Cells of Cajal in the Postnatal Murine Stomach. Gastroenterology 2008; 134: 1083-93.

13. Huizinga JD, White EJ. Progenitor Cells of interstitial cells of cajal: on the road to tissue repair. Gastroenterology 2008; 134: 1252-4.

14. Rejestr kliniczny GIST. http://gist.coi.waw.pl/index.php?id=7 - 20. XI.2012.

15. Ruka W, Dębiec-Rychter M, Rutkowski P, et al. Aktualne postępowanie diagnostyczno-terapeutyczne $u$ chorych na nowotwory podścieliskowe przewodu pokarmowego (GIST). Nowotwory 2007; 57: 181-9.

16. Miettinen M, Lasota J. Gastrointestinal stromal tumors - definition, clinical, histological, immunohistochemical, and molecular genetic features and differential diagnosis. Virchows Arch 2001; 438: 1-12.

17. Kindblom LG, Remotti HE, Aldenborg F, Meis-Kindblom JM. Gastrointestinal pacemaker cell tumor (GIPACT): gastrointestinal stromal tumors show phenotypic characteristics of the interstitial cells of Cajal. Am J Pathol 1998; 152: 1259-69.

18. DeMatteo RP, Lewis JJ, Leung D, Mudan SS, Woodruff JM, Brennan MF. Two hundred gastrointestinal stroma tumors: recurrence patterns and prognostic factors for survival. Ann Surg 2000; 231: 51-8.

19. Kazanowski M, Agrawal AK, Zawalski H, Duda-Barcik H, Kobierzycki Ch, Smolarek S, Marek G, Bobiński P, Grzebieniak Z. An unusual case presentation of a palpable abdominal wall mass: extragastrointestinal stromal tumor with literature review. Prz Gastroenterol 2013; 8: 138-41.

20. Rutkowski P. Nowotwory podścieliskowe przewodu pokarmowego. Gastroenterol Klin 2011; 3: 127-35.

21. Guzińska-Ustymowicz K, Nasierowska-Guttmejer A, Czartoryska-Artukowicz B. Znaczenie współpracy patomorfologa i onkologa w leczeniu guzów podścieliskowych przewodu pokarmowego (GIST). Onkol Prakt Klin 2012; 9: 89-96.

22. The ESMO / European Sarcoma Network Working Group. Gastrointestinal stromal tumors: ESMO Clinical Practice Guidelines for diagnosis, treatment and follow-up. Annals of Oncology 2012; 23 (suppl. 7): 49-55.

23. Pisters PW, Patel SR. Gastrointestinal stromal tumors: current management. Surg Oncol 2010; 102: 530-38.

24. Hohenberger P. Aspects of surgical treatment for gastro-intestinal stroma tumors. Radiologe 2009; 49: 1122-7.

25. Głuszek S, Rylski R, Kot M, Stanisławek J, Karcz W. GIST - ryzyko nawrotu i rozsiewu na podstawie obserwacji własnych. Prz Gastroenterol 2008; 3: 176-84.

26. Rutkowski P, Bylina E, Woźniak A, et al. Validation of the Joensuu risk criteria for primary resectable gastrointestinal stromal 
tumour - the impact of tumour rupture on patient outcomes. Eur J Surg Oncol 2011; 37: 890-96.

27. Rutkowski P, Kulig J, Krzakowski M, et al. Zasady postępowania diagnostyczno-terapeutycznego $u$ chorych na nowotwory podścieliskowe przewodu pokarmowego (GIST) w 2010 roku. Onkol Prakt Klin 2010; 6, 4: 181-94.

28. Casali PG, Jost L, Reichardt P, Schlemmer M, Blay JY, ESMO Guidelines Working Group. Gastrointestinal stroma tumors: ESMO Clinical Recommendations for diagnosis, treatment and follow-up. Ann Oncol 2008; 19 (suppl. 2): 35-8.

29. Wojtczak A. Zdrowie publiczne wyzwaniem dla systemów zdrowia XXI wieku. PZWL, Warszawa 2009.

30. Gniazdowski A. Edukacja zdrowotna. W: Zdrowie publiczne - wybrane zagadnienia. Indulski J, Jethon Z, Dawydzik LT (red.). Instytut Medycyny Pracy im. Prof. J. Nofera, Łódź 2000; 321-30.

31. Walewska E. Podstawy pielęgniarstwa chirurgicznego. Wydawnictwo Lekarskie PZWL, Warszawa 2010.

32. de Waden-Gałuszko K. Majkowicz M. Jakość życia w chorobie no wotworowej. Wyd. Uniwersytetu Gdańskiego, Gdańsk 1994.

33. Kwiatkowska A, Krajewska-Kułak E, Panek W. Komunikowanie in terpersonalne w pielęgniarstwie. Czelej, Lublin 2003.

34. Motyka M, Surmacka J. Błędy jatrogenne w opiece nad pacjentem. Pielęg XXI w. 2006; 4: 21-6.

35. Dibbelt S, Schaidhammer M, Fleischer C, Greiteman B. Patient-doctor interaction in rehabilitation quality and long-term treatment results. Patient Educ Couns 2009; 3: 328-35.

36. Garfinkle CL, Block P. Physicians' interactions with familie of terminally ill patients. Fam Med 1996; 28: 702-7.

\section{Address for correspondence}

\section{Grażyna R. Wiraszka}

Institute of Nursing and Obstetrics

Faculty of Health Sciences

Jan Kochanowski University in Kielce

Al. IX Wieków Kielc 19

25-317 Kielce, Poland

e-mail:wiraszka@ujk.edu.pl

Submitted: 30.07 .2013

Accepted: $\quad 3.02 .2014$ 